\title{
SITUAÇÃo DE SíTIO
}

IUMNA MARIA SIMON

\section{RESUMO}

No panorama recente da poesia brasileira surpreendeu o aparecimento, em 2001, do poema "Sítio", de Claudia Roquette-Pinto, poeta até então tida como intimista, metaforizante, trancada no seu mundo privado e burguês. $\mathrm{O}$ foco desta abordagem é discutir como foi possível à autora formular nesse poema um estudo sobre o medo e a violência, sem abrir mão da sua imagética introspectiva e da sua experiência poética anterior, centrada numa escrita referencialmente rarefeita. A análise em detalhe do poema procura registrar a conversão da opacidade, do lacunar e da indeterminação em elementos de caracterização da violência urbana e da miséria emocional dos protegidos. Aí se entrelaçam portanto a atualidade do processo histórico-social brasileiro, a vulnerabilidade da poesia e as carências do sujeito poético.

PALAVRAS-CHAVE: poesia brasileira contemporânea; violência urbana; representação; Claudia Roquette-Pinto.

\section{SUMMARY}

Brazil's literary scene was stirred in 2001 by the publication of the poem "Sítio", by Claudia Roquette-Pinto, who until then was considered an intimist poet, prone to metaphorization, and locked up in her own bourgeois world. This essay aims to discuss how the author could develop in that poem an understanding of fear and violence, without giving up her introspective imagery and her previous poetic experience, which is concentrated in a referentially scarce writing. The in-detail text analysis intends to register the poet's conversion from the realm of opacity, lacunae, and indetermination to the characterizing of the urban violence and emotional misery that afflicts the privileged ones. Thus our analysis seeks to combine the implications of Brazil's present social-historical reality with the vulnerability of the poetry and the needs of the poetic self.

KEYWORDS: contemporary Brazilian poetry; urban violence; representation; Claudia Roquette-Pinto.

"eu escuto o que tem que ser dito"

Claudia Roquette-Pinto, "no jardim", em Os dias gagos

Nocurso da maisvertiginosa transformação da sociedade brasileira, marcada pelo fim das políticas de desenvolvimento, pela estagnação econômica com aumento da concentração de renda, período em que o cosmopolitismo financeiro e a desfaçatez ideológica dos neoconservadores andaram de rédeas soltas, esperávamos tudotudo mesmo - , menos que coincidisse com esses anos um novo ciclo de retradicionalização da poesia. Retradicionalizar significa incorporar as tradições modernas, traduzir o teor originariamente crítico delas em formas convencionais e auto-referidas, mediante o trabalho de 
linguagem e sob o amparo do "rigor de construção", paradoxalmente assumidos como princípios capazes de preservar a autonomia poética e o ofício do verso. Como se vê, fundem-se aí vários horizontes da experiência moderna: a abertura historicista trazida pela existência de um museu da poesia moderna, a consciência formal do poema como artefato lingüístico, o teor construtivo das vanguardas dos anos 1950, a antiga autonomia esteticista e até, quem diria, o gosto provinciano pelo artesanato do verso. De imediato, esse movimento sem programa parecia reagir à desqualificação formal e à baixa mímese a que os poetas marginais haviam submetido a poesia brasileira nos anos 1970, embora tendesse a escapar ao compromisso dos confrontos. Sob a fiança de linhagens prestigiosas da tradição moderna e já sem propósito radical, a invenção poética se desloca da experimentação dos procedimentos (como no tempo da vanguarda) para a conceitualização dos conteúdos, tratados frivolamente como matéria de variações. O que mudou nesse quadro foi o peso e o sentido da tradição, que não parece incompleta, nem é considerada obstáculo, sequer precisa ser superada ou transformada — agora todas as tradições estão franqueadas, conquanto o poema desarme a inquietação autoproblematizadora, caracteristicamente moderna, à procura de dicções elevadas e pluralistas que desrealizem sua matéria ao mesmo tempo que a ornamentem ${ }^{1}$. Pensando bem, uma retradicionalização desse tipo, que reafirma linguagens já testadas e reassegura a soberania do poético, só poderia mesmo se converter numa proposta de renovação, ou reação às poéticas existentes, num período de regressão social e econômica, como o que ocorreu simultaneamente ao auge do pós-modernismo internacional, na segunda metade dos anos 1980. Por estranho que pareça, ou por tudo isso, uma época de tamanhas transformações e conseqüências sociais, como as das duas últimas décadas do século passado, não contou no Brasil com um ponto de vista artístico relevante da parte da produção poética. A poesia deixou de ser companheira de viagem do presente, deu as costas aos acontecimentos, os quais no entanto a afetavam no mais íntimo de sua capacidade criativa.

Mais do que uma simples volta antivanguardista ao literário, essa retradicionalização bastante frívola foi uma forma de acomodar a crise da representação em moldes aliteratados e poetizantes. Em tais circunstâncias, restou aos jovens criadores - e a outros já não tão jovens - a recombinação desencantada de erudição, o jogo de referências literárias e artísticas, dentro do espírito genérico da intertextualidade pós-moderna, que no caso brasileiro veio auratizar o poema e sublimar o presente. A escrita abstrata e descarnada precisou se "poetizar", disfarçando a rarefação referencial e a indeterminação discursiva, ainda que subsistissem nela muitas manchas de divagação lírica, confessionalismo e alguma reflexão existencial. De outro ângulo, pode-se
[1] "Tudo hoje é campo de experimentação ao mesmo tempo: das formas fixas aos suportes e gêneros absolutamente mesclados, o que pressupõe uma estratégia que, a princípio, não recusa nada, e de alto risco porque exige jogadores cada vez mais treinados em quaisquer regras de jogos. [...] Mas o interessante é a convivência civil desses registros, momentaneamente possível" (Ronald Polito. "Notas sobre a poesia no Brasil a partir dos anos 70". Cacto. Poesia \& Crítica, São Paulo: n², 2003, pp. 70-71). Como se vê, a simples constatação vai se tornando gradativamente uma justificação, que converte o ponto de chegada da poesia contemporânea numa espécie de destino. 
[2] Tarso de Melo. Planos de fuga e outros poemas. São Paulo/Rio de Janeiro: CosacNaify/7 Letras, 2005, e Ronald Polito. Terminal. Rio de Janeiro: 7 Letras, 2006.

[3] De Ricardo Domeneck: Carta aos anfibios. Rio de Janeiro: Bem-Te-Vi, 2005, eA cadela sem Logos. São Paulo/ Rio de Janeiro: CosacNaify/7 Letras, 2007.

[4] Frederico Barbosa. Louco no oco sem beiras. São Paulo: Ateliê Editorial, 2001.

[5] Idem. Contracorrente. São Paulo: Iluminuras, 2000. De Régis Bonvicino: Ossos de borboleta. São Paulo: Editora 34, 1996, e Página órfã. São Paulo: Martins, 2007.

[6] Fabio Weintraub. Novo endereço. São Paulo/Juiz de Fora: Nankin Editorial/FUNALFA, 2002. dizer também que, com a rotinização e o esgotamento da vanguarda, o que sobreviveu desta no período deixou de ser matriz de experimentação para se tornar um ideal de alta cultura, depuração e refinamento poéticos e, acima de tudo, intérprete da tradição literária mundial. Todos esses elementos convivem, como se sabe, contraditoriamente, na poesia concreta desde os seus primórdios e, por essa razão, ela pôde atravessar os decênios de 1980 e 1990 ainda como um padrão válido, suprindo com suas posições mais recentes a falta geral de debate estético ou programa poético.

A partir dos últimos anos de 1990 surgiram indícios de mudança no panorama, sinalizando talvez que a retradicionalização pósmoderna perdia fôlego. Sinais esparsos mas indicadores de que algo entrava em movimento e poderia alterar os termos que possibilitaram o chamado boom produtivo da poesia. Pouco a pouco, a sintaxe deixa de ser um recurso de obscurecimento do assunto, cuja dissolução se convertia em espetáculo, como é recorrente na obra de Carlito Azevedo. Ou seja: o poema que espetaculariza a proliferação e a desmontagem de suas imagens perde espaço para uma poesia de horizonte oprimido e desanimado, de rotina de ninharias, como se lê nos livros de Tarso de Melo e Ronald Polito². Redescobre-se o tom menor associado a contextualizações mais densas e pessoais, que pode se conciliar com algum experimentalismo da linha gráfica e do arranjo em blocos fora de sincronia com o ritmo e a enunciação - como nos poemas de Ricardo Domeneck3. Ressurge o interesse pelo poema em prosa e certos impulsos de narratividade como os que percorrem, entremeados à rarefação, os Planos de fuga e outros poemas, de Tarso de Melo, ou Louco no oco sem beiras, de Frederico Barbosa, uma composição feita de poemas breves que se reestruturam no corpo narrativo de um livro4. Também é curioso que a poesia concreta tenha gerado, nessa altura, em autores mais ou menos tocados por ela, ou em crise com, uma poesia de protesto, reclamação, indignação e desespero existencial como se vê neste último título e em Contracorrente, do mesmo autor, assim como na produção de Régis Bonvicino a partir de Ossos de borboleta, culminando com a crítica feroz de Página órfã, que a mais de um resenhista pareceu poesia política5. O assunto volta a ser relevante (sic), exigindo a precisão no seu tratamento, o que pode ter as conseqüências de um retorno ao real, se não for uma demasia a expressão. Esse retorno, narrado com um timbre claro e sereno que provoca desconforto, aparece igualmente em Novo endereço, de Fabio Weintraub, que se detém em situações de sofrimento da intersubjetividade em meio a destroços indistintos de fábricas, peças, corpos, em meio a dentes, unhas, pés ${ }^{6}$. Evidências dessa alteração são a volta da referencialidade concreta, do país real, dos problemas sociais, da decadência urbana, por vezes mesclados ao padrão impositivo da intertextualidade. Em Cais, de Alberto Martins, 
a descrição da cidade-porto (Santos e cercanias), incrustada na paisagem de lodo e luto, quer desfazer a euforia culturalista do modernismo que valorizou a informalidade populare a miscigenação geral, as quais já não podem ter lugar na elegia de um país que não passa de uma triste e permanente infecção colonial7.

De lá para cá, o índice de insatisfação cresceu muito, a ponto de a crítica jornalística com falta de jeito apressar-se em rotular alguns exemplares dessa linha como "neoparticipante" ou como uma "retomada da poesia engajada" 8 . Hoje lemos poemas e livros inteiros que abordam a desagregação da sociedade brasileira, nome mais específico para o contemporâneo, cuja matéria inclui obviamente pobreza, marginalidade, mendicância, crianças de rua, catadores de lixo, classe média empobrecida, violência urbana, tráfico de drogas, criminalidade. Tudo isso pede uma reformulação das questões que o ciclo da retradicionalização antes nos propunha, embora esta ainda continue em vigência, ou continuará por bom tempo como coadjuvante. Mas a questão que me interessa aquié saber por que uma poética ancorada na rarefação, ou então na dissolução da referência, quer agora contextualizar a referência? É possível dentro da poesia feita de poesia essa volta?

Que surpresa não foi para os leitores o aparecimento de "Sítio"9 da parte de Claudia Roquette-Pinto, a poeta contemporânea que parecia até então trancada no seu universo privado e burguês, alinhada a uma poesia delicada, erótica e feminina. É bom lembrar que ela começou a escrever nos anos 1980 mas nunca adotou o tom confessional nem usou a imaginação poética, como fazia a poesia liberada daqueles tempos, para apresentar a mulher como sujeito, como pólo ativo e manipulador (recuperando o imaginário patriarcal do ângulo feminista). Ao contrário, retomou certa expressividade, tons e tópicas tradicionais do lírico para escapar aos clichês do feminismo, reconhecendo quem sabe que a "liberação" deu problema e o quanto tal emancipação tinha de insatisfatória.A melhor definição dessa estratégia chegou com o livro cujo títuloé justamente Corola ${ }^{10}$, publicado em 2000 , em que seu jardim imaginário assinalava com um quê perverso tal dissidência. Quase ninguém viu a provocação desse jardim que não conhecia ruptura alguma entre público e privado. Apontada muitas vezes como intimista, metaforizante, fechada em si mesma e fora da vida, Claudia certamente escreveu "Sítio" para responder à incompreensão que cercava o seu trabalho.
[7] Alberto Martins.Cais.São Paulo: Editora 34, 2002.

[8] Numa resenha de três livros de poesia lançados em 2007, Fabrício Carpinejar diz: "A principal força da tripla aparição é a retomada da poesia engajada. Ela se torna possível, desde que feita sem partido e finalidade. É distinta poesia política, fundada na ironia inteligente, numa cadeia imaginária e solidária entre os amigos e na readequação do verso à síncope urbana.Abruptos quando necessário, mas sem sacrificar o lirismo". "Livros retratam a pulsão da capital paulista". Caderno 2, O Estado de S. Paulo, 27/01/2008, p. D-2.

[9] Publicado pela primeira vez na revista Inimigo Rumor. Rio de Janeiro: Viveiros de Castro Editora, $\mathrm{n}^{\mathrm{9}} 10$, maio 2001, p. 54). Republicado em outras revistas de poesia, em versões modificadas, foi incluído como poema de abertura do livro Margem de manobra. Rio de Janeiro: Aeroplano Editora, 2005, pp. 11-12.

[10] Claudia Roquette-Pinto. Corola. São Paulo: Ateliê Editorial, 2000.

\section{"Sítio"}

O morro está pegando fogo.

$\mathrm{O}$ ar incômodo, grosso,

faz do menor movimento um esforço,

como andar sob outra atmosfera,

entre panos úmidos, mudos, 
num caldo sujo de claras em neve.

Os carros, no viaduto,

engatam sua centopéia:

olhos acesos, suor de diesel,

ruído motor, desespero surdo.

O sol devia estar se pondo, agora

- mas como confirmar sua trajetória

debaixo desta cúpula de pó,

este céu invertido?

Olhar o mar não traz nenhum consolo

(se ele é um cachorro imenso, trêmulo,

vomitando uma espuma de bile,

e vem acabar de morrer na nossa porta).

Uma penugem antagonista

deitou nas folhas dos crisântemos

e vai escurecendo, dia a dia,

os olhos das margaridas,

o coração das rosas.

De madrugada,

muda na caixa refrigerada,

a carga de agulhas cai queimando

tímpanos, pálpebras:

O menino brincando na varanda.

Dizem que ele não percebeu.

De que outro modo poderia ainda

tervirado o rosto: "Pai!

acho que um bicho me mordeu!" assim

que a bala varou sua cabeça?

É um poema construído por incertezas, desde o primeiro verso, pela hesitação entre o que se sabe e o que não se sabe, ou pela indecidibilidade, para usarmos um termo da moda, mas indecidibilidade aqui estranhamente ligada a recursos da descrição. Tem o poeta condições de ver e descrever o que ele vive, se nem sabe que acontecimento éesse? A construção coloquial "[O morro] está pegando fogo" funde planos de sentido que vão do referencial imediato (incêndio), à locução popular corrente (tem briga, tem complicação, tem bafafá), à transposição metafórica: atmosfera de medo e desespero com chamas, fumaça, fuligem, reais ou não. Assim como o título admite muitos significados (lugar definido, terreno, pequena fazenda, assalto, ataque, estado de

[11] Ver a análise de Marcelo Sandmann, "Poesia em estado de sítio", que faz um levantamento exaustivo das possibilidades referenciais do poema (Sebastião, São Paulo: $\mathrm{n}^{\mathcal{Q}} 2$, 2002, pp. 82-87). sítio ${ }^{11}$. O horizonte está nublado, empoeirado, enfumaçado, irrespirável, não se enxerga nada, não se pode sequer saber se o sol está se pondo - um clima de sufocação que culmina na imagem do "céu invertido", equivalente à tópica do "mundo às avessas", figura clássica 
de catástrofe, de mundo fora-de-ordem. O poema está centrado numa natureza hostil, convulsionada por uma corrente opressora, contra a qual não há consolo, não há saídas. Mas que conflagração é essa que altera tudo, o ar, o movimento do corpo, o trânsito e os elementos da natureza? E que transtorna as imagens, expandidas em metamorfoses sucessivas que conferem atributos animais ou humanos aos carros, ao engarrafamento, à beira de uma espécie de desespero autista ("desespero surdo" contraposto a "ruído motor").

A metamorfose do dado objetivo em digressão metafórica é construída pela seqüência de sete blocos oracionais delimitados por ponto, exceto o último em que dois pontos anunciam a citação de uma notícia, escrita ou falada, aparentemente elucidativa. Todos os blocos são compostos para explicar o verso inicial, cuja condensação de sentido merece ser desdobrada e parafraseada, embora nada se esclareça suficientemente, ou melhor, nem o fato bruto oferece a referência que falta para completar a contextualização. Nessa atmosfera de distinção difícil, criada pela indecidibilidade e pelos deslizamentos de sentido, não há causas nítidas ou determinantes - até a bala é um bicho, a fala da vítima, um equívoco.

Claudia Roquette-Pinto é poeta que manteve interlocução por assim dizer sistemática com várias frentes da poesia contemporânea (Poesia Concreta, Sylvia Plath, Paul Celan, Language Poetry, entre outros), além de uma experiência comum ou geracional afinada com poetas brasileiros de tendências diferentes, como Carlito Azevedo, Régis Bonvicino e Antonio Cícero. Mas desde o início ela, que não se fechou numa tendência só, fundiu experiências internacionais e nacionais preferidas, incluída a vanguardista, e vinculou sua mescla a uma tremenda carência lírica. É o que cria o curto-circuito da força artística do poema de que tratamos.

"Sítio" se estrutura portanto a partir de um complicador: a dificuldade em lidar com a referência, porque Claudia participa daquela tendência contemporânea dominante que cultiva a desrealização do referente, o lacunar, imagens obscuras e autônomas, a pura textualidade das designações em cadeia, cuja prática poética não se disciplinou na relação com o dado imediato da realidade. Daí a ousadia de um poema como esse, que está experimentando a partir de uma poesia referencialmente rarefeita a explicitação referencial, sem abrir mão da imagética introspectiva que é própria da autora. E como ela faz isso? Mostrando ou criando afinidades entre o seu mundo mais privado e a situação social do Rio de Janeiro, do morro, da violência urbana, entre as suas imagens secretas e prediletas e esse mundo lá fora. "Sítio" generaliza para o espaço urbano sentimentos e sensações que a poeta desenvolveu no âmbito de sua própria insatisfação, explicando desse modo a psicologia aparentemente reclusa de Corola. Pois foi a partir 
[12] Claudia Roquette-Pinto, Corola, p. 19.

[13] Idem, p. 49.

[14] Em depoimento na mesa-redonda "Poesia tem sexo, sexo tem poesia?" (Itaú Cultural, SP, 22/11/2004), Claudia Roquette-Pinto declarou que os temas básicos de sua poesia são amor eguerra.

[15] Não foi a impressão que na época teve Carlito Azevedo ao resenhar o livro: "A metáfora é um instrumento perigoso, tanto pode ser nociva, ao transformar qualquer coisa em qualquer coisa, anulando a diferença e especificidade de cada coisa, como pode ser 'revelação', como se pela metáfora o que falasse fosse justamente a voz da diferença. Felizmente, em Corola, há uma predominâcia deste segundo tipo de metáfora, como no caso da estranha e forte "árvore de fogo', ou do 'buquê de ruídos' que as abelhas inauguram sobre uma flor de cerejeira. Mas há também metáforas meramente retóricas, nada distantes do ornamentalismo retórico da geração de 6o: 'despir a esperança'/ como uma mortalha'//Arrisco aqui queessa ultrametaforização do mundo tem relação absoluta com o fato da autora colocar entre parênteses a experiência urbana" "A vida como metáfora", no. com.br, 16 de novembro de 2000 , no site www.no.com.br/revista, acessado em 14/03/2004. deste livro que seus poemas passaram a tratar do medo e da violência por meio de dilemas perceptivos e sensoriais: "Suspenso na rede do sono na tarde indecisa/ em ser, ainda, tarde, ou ver-se noite/ o corpo, em seu torpor, não acredita/sequer na hipótese de um corpo/(em morte, em vida, e/ o que dizer do encontro)" ${ }^{2}$. Ou: "Dentro do pescoço/ o poço, vazio,/ caindo intempestivamente/ até que o fio/ da expiração se estique/ o ar arrebente o dique/ do que insiste em ser/ oco [...]"13. Neste conjunto de poemas inquietantes, que fogem ao ramerrão da produção contemporânea, existe um estudo obsessivo de processos de introspecção e descontrole, muitos deles traduzidos em situações incessantes de vertigem e queda. Tais processos compõem uma estrutura radical de insatisfação, cujas figurações imagéticas, por vezes perversas e até masoquistas, revelam o quanto o ensimesmamento está tomado pela sociedade presente; o jardim, ou seja, o mundo privado, já fora invadido pela conturbação externa (a mesma de "Sítio"?) e o sujeito poético dilacerado pela violência de sua imaginação e de suas emoções - em Corola são os próprios sentimentos que estão em estado de guerra ${ }^{14}$. Digamos que aí a poeta estivesse buscando técnicas para expor o custo físico e emocional de sobreviver no inferno da violência urbana, que não é diretamente nomeado, mas figurado em muitas variações de aflição, pânico, insegurança e asfixia, sempre dentro do pequeno território de um jardim, quase um mundinho dickinsoniano de flores, bichinhos, vida e afazeres caseiros ${ }^{15}$.

Em resumo, Claudia traz para "Sítio" os símbolos desse universo recluso ejoga-os para o plano explícito da realidade, usando todavia os mesmos recursos poéticos anteriores, a par do descontrole expressivo que lhe é próprio, para incluir no poema a circunstância do dia-a-dia do Rio de Janeiro, ainda que não a domine por inteiro e deixe expostas as dificuldades e limites dessa inclusão. Observe-se a recorrência de imagens características de toda a sua poesia, geradas por referências domésticas (panos úmidos, caldo sujo de claras em neve), amorosas (coração das rosas), arquitetônicas (cúpula), florais (crisântemos, margaridas, rosas), as quais ela agora pretende remeter ao contexto da violência urbana. Para aumentar a estranheza, o acontecimento é narrado como um fenômeno natural, atmosférico ou climático, inclusive pelo uso de prosopopéias alucinadas de predileção da autora, como se lê no quinto bloco: o mar, que aí não se abre para horizonte algum, é representado como um cachorro hidrófobo em convulsões deespuma, sempre à beira da morte. A desordem é acompanhada pela natureza, como se a premonição de morte fosse aos poucos engendrada pela própria paisagem, naquele sítio. Esta opção descritiva, por sua vez, prepara e acentua a quebra do bloco final.

De um foco aparentemente centralizado, o poema apresenta diferentes tomadas da zona do conflito (o morro, o ar, os carros, o sol 
e o céu, o mar, o fuliginoso jardim, a caixa refrigerada, o menino na varanda), as quais, por assim dizer, deslizam ou se alternam da angulação objetiva para a subjetiva. Os versos mais denotativos, como "Os carros, no viaduto", logo se transformam numa metaforização irritada até chegar ao auge do desespero anônimo. A autora joga sistematicamente, desde a primeira linha, com a possibilidade de a informação denotada ser corroída e modificada pela gratuidade da imagem poética. Outro recurso influente para o deslocamento do sentido, num fluxo contínuo até os dois pontos fatais, é o reforço de tonicidade (assim Antonio Candido designa a tendência a extrapolar o esquema rítmico convencional do verso medido pela multiplicação de tônicas intermediárias), que sobrecarrega o verso com acentuações fortes, espelhadas pelas rimas toantes, gerando um efeito de suspensão, opressão elerdeza que subjetiviza a denotação: "[o] mOrro estÁ pegAndo fOgo./ [o] ArincÔmodo, grOsso,/fAz do menOr movimEnto um esfOrço". Esse modo de trabalhar os planos objetivo e subjetivo assinala a dificuldade de separá-los em meio à conflagração e o quanto o acontecimento externo contamina a intimidade.

São vários os fatos e acontecimentos que ocorrem em momentos diferentes do dia:no entardecer (meio indeterminado) e na madrugada (mais definida). Entre eles há uma indicação temporal no pretérito perfeito("deitou") quequebra a descriçãodo presenteimediatoeintroduza duração temporal (pela locução gerundiva "vai escurecendo") na rotina ininterrupta de fumaça, fuligem e sufocação - "penugem antagonista" - que contamina "dia a dia" as flores do jardim privado como uma espécie de floração nova e ecológica do medo. O episódio do menino e da bala perdida é um desses fatos, porém acrescentado à composição sob a forma explícita de colagem de notícia ou relato oral - fecha o poema em chave ultra-realista que, em retrospecto, transforma o que veio antes. Usuais na poesia de Claudia, colagens de materiais externos, na forma de excertos tirados de outros textos ou de empréstimos de passagens, partes de frase ou palavras, aparecem freqüentemente destacados pelo itálico, expondo a convergência entre a circunstância do poemaeas leituras da autora, muitas casuais como ela mesma assume. A inserção arbitrária, muitas vezes prosaica, comenta de outro espaço a carência lírica que se formulava por introspecção, para ressaltar salvo engano que esta é dessacralizada e não dispensa o dado objetivo mesmo que colhido em leituras passageiras. Ou então para ressaltar que a impureza do lirismo admite a situação parafrástica, a glosa infinita, certa intertextualidade ou ironia despistadora. Em "Sítio" não há gratuidade, a citação em itálico cola no texto um pedaço de notícia que desvenda (em parte) o significado das cadeias imagéticas anteriores, lançando a opacidade destas noutro patamar, menos cifrado ou alusivo. Estranha à empostação e ao padrão imagético dominante no poema, a aposição 
[16] Ou como sugere Marcelo Sandmann: "A bala terá certamente sido disparada no primeiro verso, para chegar a seu alvo no verso derradeiro, depois de uma distensão temporal impressionante e uma trajetória que agrega/ desagrega todo o complexo de espaços (naturais e sociais) da grande metrópole"(op. cit., p. 86). realista do episódio da bala perdida tem sua dose de indeterminação, melhor, de incerteza, análoga às digressões metafóricas e prosopopéias. Tanto que, no coração da notícia, a fala do menino vem transcrita em tipo redondo, como se já estivesse incorporada ao texto e fosse justamente ela também uma fala da poeta.

Até onde posso ver, o poema confronta uma situação protegida de medo (no abrigo de um sítio, um apartamento, uma casa, o que for) com a cena da criança exposta a uma bala perdida numa varanda (quando?). É este o instante de rompimento da condição protegida nessa varanda vulnerável, momento em que a vítima perde por assim dizer a proteção imaginária de seus medos. O arranjo formal atesta que a poesia que oferece proteção por imagens falha diante da bala perdida e precisa empreender uma volta à referência, mesmo que com isso se rompa o ritmo, a imagética e o timbre da escrita. Por ser o poema meio desconjuntado, na alternância de registros descritivos e expressivos, o achado poético é notável, ao reproduzir o mesmo desconhecimento da criança sobre o que se passa — vide a fala inadequada do menino num momento grave: "Pai! acho que um bicho me mordeu!". Vejo aí a sugestão de similaridade entre a criança baleada e o ponto de vista do poeta, cuja posição é equivalente à do menino que morre sem saber o que está acontecendo e pronunciando uma fala também imagética (mordida de um bicho pateticamente metafórico).

Uma onda de perplexidade retroage pelo poema todo. Nesse sentido, a grande fala que o poeta poderia enunciar seria com toda a probabilidade uma expressão errada numa hora errada - de quem morre por acaso ou por engano por uma bala perdida (sugestão reforçada pela tipologia ${ }^{16}$. Esta pode ser uma alegoria do queé fazer poesia hoje numa sociedade como a brasileira: o testemunho que o poeta pode dar está aquém dos acontecimentos, ele não tem uma visão clara do que está se passando, sua solidariedadeé restrita e seu alcance político nulo.Aqui a indecidibilidade se torna fator de agonia, medo, desespero e cria um clima de aberração e emudecimento, pois a voz que o poema acolhe como sua é a voz de um morto. A fala da criança, apesar do engano, tem uma espécie de clareza inútil e terminal sobre a psicologia do estar em sítio.

Lembro que a palavra que indicia presença humana está situada em posição sintaticamente indeterminada nas duas ocorrências: "entre panos úmidos, mudos" e "De madrugada,/ muda na caixa refrigerada," (além do possessivo de "e vem acabar na nossa porta"). A mudez dá pista de que o humano está intimidado, deixando ver na referência cifrada uma intenção generalizante. A mesma intenção de "tímpanos, pálpebras:", perdidos no meio do tiroteio, sem ouvir e enxergar, mas destacados pelo corte do verso. Todos estão mudos em "Sítio", menos o menino que solta suas últimas palavras em meio a um mar de ruídos, fumaça e tiros. 
Apesar dos dêiticos de proximidade (agora, desta, este, nossa)e dos verbos no presente, que organizam as relações espaciais e temporais do discurso, a ausência de marcas explícitas da subjetividade tem sentido forte, a indicar o estatuto instável do sujeito na figuração da cena e sobretudo que a circunstância individual conta pouco para entendê-la e explicá-la. Ainda assim, a poeta cria imagens e sonoridades para algo de que não sabe a extensão nem o teor real, todas marcadas, como vimos, pela indeterminação do que é objetivo e subjetivo: a atmosfera de fora é sentida por um corpo caseiro como andar em claras em neve, assim como o sol não pode ser avistado sob a poeira. A própria existência do mar que traz conforto interior vem agora, em movimento contrário que anula a quietude da contemplação, morrer ao mesmo tempo como imagem e realidade. Desse modo, o sujeito vai assumindo que não domina nem temporal nem espacialmente o problema que está abordando, sempre em busca de algo maior que transcende a experiência pessoal e coletiva, mas que não se sabe o que é e pode ser uma experiência traumática. A imagética sensorial e perceptiva está ao longo do poema associada às limitações do corpo, que não alcança a cena. O corpo está emperrado, travado; mesmo os corpos dentro dos carros também não conseguem atravessar esta "cúpula de pó". Os objetos perdem nitidez até que a enigmática "carga de agulhas cai queimando/ tímpanos, pálpebras:", como se fosse o fogo anunciado na abertura. A violência banalizada está patente nos objetos, utensílios e tarefas diárias, ou no jardim, cada coisa transmutada pelo medo em metáforas vagamente autônomas, cuja aparência ameaçadora mimetiza a percepção de quem tudo experimenta como espectador aterrorizado (testemunha que não enxerga). O corpo vai sendo arrastado a seu limite, testado na sua capacidade de agüentar a pressão, que pode ser tão concreta quanto o próprio medo. Enfim, tudo o que diz respeito ao corpo está marcado por lentidão, mudez, intransparência, paralisia, enquanto a notícia proveniente de uma fonte externa (rádio? televisão? voz?) é clara, nítida, objetiva. É a sinopse esclarecedora que chega para situar toda a cena. Contudo, a carga estetizante dos versos anteriores era aflitivamente opaca, ao passo que a informação externa e em itálico, que oferece uma verdade simples e direta, a chave dos acontecimentos descritos, capta muito pouco da experiência do poema. A sucessão de imagens fragmentadas e poetizantes registrava a miséria do corpo, com sua imaginação reduzida a paranóia e medo, sem discernimento maior e sem reação crítica. Mas se o factual da notícia rompe aquela cadeia imagética, a poetização não exclui o factual, ganha com sua inserção. Eis o alcance desta construção formal que, entre outros acertos, é também uma maneira de mostrar que um poema difícil, enigmático, sobre uma situação já corriqueira nas grandes cidades brasileiras, rebate a urgência da mídia, que naturalizou e ba- 
nalizou a violência, tanto quanto se subtrai às exibições de denúncia ou compaixão literárias, que por sinal são mesmo inúteis diante do tamanho e da irresolução do problema.

A propósito, com finalidade de comparação, vale a pena mencionar aqui o último livro de Régis Bonvicino, Página órfã, que surpreendeu por acentuar e expandir, em larga escala em relação a seus livros anteriores, a precisão da referência para dar conta da conjuntura de guerra e luta social que atravessamos. Nele se encontra a mesma matéria do poema de Claudia, embora seu registro direto seja agressivo, os elementos líricos permaneçam intocados, os materiais de colagem e o zapping de linhas, marcados pelo realismo incisivo, pareçam anunciar uma enérgica resposta política. Este livro que, se arrisca muito no enfrentamento do resultado da crise do capitalismo contemporâneo, apanhada em múltiplas situações, países e línguas, extravasa uma indignação aparentemente explosiva, uma gesticulação exacerbada de ativismo que não articula (sobrepõe apenas) as imagens do horror econômico. O poeta percorre freneticamente cenas de cidades apinhadas de pobres e mendigos, ruas cheias de lixo e sucata, ao lado do exibicionismo dos ricos, da indústria da moda, dos ícones do consumo, como se a poesia, transcrita numa objetividade ostensiva, tivesse o frescor do grafite. Mesmo que tudo seja invariavelmente exposto em fragmentos, citações, recortes, a plenitude literal do mundo on-line a apodrecer fica sempre preservada para assegurar a radicalidade dessa exposição vexaminosa. Tudo é feio, fétido, podre, obsceno, e esse pitoresco negativo é tão espetacular quanto é exultória a violência antidiscursiva do poeta. Cenas e imagens irrompem (ou nos atacam) esquematicamente, como numa peça publicitária ou deagit-prop:a máquina de contrastes dos poemas está sempre equiparando sujeira e consumo, selvageria e técnica, top models e mendigos. Em contraponto à barbárie total surgem recorrentemente, em espaço contíguo, instantes de lírica da natureza, flores evegetação de nomes raros, assinalando o ritmo eterno e indiferente da natureza como uma pastoral dentro do lixo. Negatividade artística para Bonvicino é o poema deliberadamente grosso, antipoético, repleto de miséria e sujeira, mas cuja abjeção é um termômetro da fibra de quem o escreveu.

Noutras palavras, o resultado lamentável de uma era de globalização e neoliberalismo se converte por um reducionismo gritante em Página órfã na contraposição da desgraça dos pobres à obscenidade escandalosa dos ricos e famosos, contraposição que se repete vezes sem conta - o que é muito pouco para uma poesia política que ainda apregoa dialogar com a Language Poetry. Nessa militância imaginária, entre indignação e fúria, Bonvicino dispensa qualquer simpatia social, confiando apenas na heroicização positiva de sua negatividade. Afinal, a sociedade contemporânea éum mundo que não pode ser compreendido 
mas tão-somente odiado (o ódio é aqui alçado a reação política), e a espetacularização da catástrofe pode ainda oferecer uma saída honrosa, ou uma construção regeneradora, para o poema em meio a tanta degradação, da qual ele está fora. Tal como a borboleta do poema "Página", que sabe de ramo em ramo reinventar seu mimetismo, o poeta vê que o que existe mesmo é "a flor da azálea / o lixo real, / e o verdadeiro / desta página"17. Fabio Weintraub, que discutiu o lado moralizador da escamoteação (pós-moderna?) desse sujeito poético, apontando o sistema de compensações que subsiste nas ambivalências da fé última na verdade da poesia, observou certeiramente: "Sobretudo no que tange à venalidade, o tom de reprimenda é ainda reforçado pela marca de distinção que o eu lírico se atribui, figurando-se como um 'mau negociante de inutilidades', fabricante de algo que não se vende, portador da redentora "praga das palavras" ("Prosa").// Em contrapartida, nos poemas habitados por mendigos e toda sorte de refugo humano, não há propriamente deslocamento ou cisão da voz lírica [...] - ela não assume o ponto de vista daqueles a quem retrata, nem se instabiliza radicalmente a ponto de prescindir de pausas epifânicas" 18 .

Mas como tratar a violência e não apenas incluí-la no poema? Claudia Roquette-Pinto não se furta à dureza dos fatos, interessada que está no estudo do medo como matéria de uma poesia que tenha pertinência para o seu tempo. Está interessada em figurar o império de uma violência indeterminada e disseminada, que molda o ritmo do cotidiano, colonizando a cidade, deturpando o sistema emocional de seus habitantes. Tudo é neuroticamente normal nesse sofrimento recolhido em meio ao caos - é um ângulo perplexo e rotinizado, bem diferente da objetividade assertiva e vistosa com que Régis Bonvicino registra em Página órfã a aberração que avassala uma sociedade dividida entre a miséria das ruas e o desaforo do consumismo. Voltando a "Sítio": aí se valoriza a contaminação entre externo e interno, entre o eu e o que está pegando fogo, em seu sofrimento sem distância ou escapatória, pois a desestruturação do mundo privado coincide na sua descrição com a conflagração morro afora. Talvez seja o caso de ressaltarmos na solução poética de "Sítio" a ousadia de uma técnica um tanto enviesada, mas eficaz, de encostar na vida. Não há brutalismo, portanto não se privilegia a excitação hedonista do consumo da violência com seu excesso de abjeção, por meio de imagens chocantes e abstratas - como faz a mídia o tempo inteiro, franqueando uma ilusão de proximidade que dessensibiliza e dessolidariza. Tanto é verdade que a colagem de um relato não implica em "Sítio" sobrecarga factual alguma, ou valorização do documento ou da informação prévia, visto que a referencialidade e a literalidade são postas em dúvida pelo todo do poema, cuja contundência depende do confronto de imagem e realidade. Em linha contrária ao fetiche da literalidade, a presença da violência ressalta o
[17] Bonvicino, Régis. Página órfã, op. cit., p. 84 .

[18] Fabio Weintraub. "Caos moralizado". KJornal de Crítica. São Paulo: $\mathrm{n}^{\mathrm{Q}} 12$, junho 2007 , p. 7 . 
[19] O que pode significar uma caixa assim, ainda por cima reforçada pela gelada e entorpecedora rima "madrugada/ refrigerada": um quarto? um apartamento? ou uma gaveta de necrotério?...

[20] Desenvolviesse aspectoem "Revelação e desencanto: a poesia de Valdo Motta". Novos Estudos, São Paulo: Cebrap, $\mathrm{n}^{\mathrm{Q}} 70$, novembro 2004, pp. 209-33. torpor físico num espaço social que se estreita, confinando a atividade mental a uma profusão de fantasias de destruição, neuroses e fobias (a mesma que leva a indústria do medo a sempre clamar por um reforço de repressão e segurança). Alastrada pelo poema, a violência se desdobra em temas conexos como proteção imaginária, desproteção real, incomunicação, fetichismo, terror, opressão física e psíquica, que desenham um quadro objetivo mais complexo e nuançado da dissolução da sociabilidade, a qual se reflete no indivíduo confinado. Mesmo fora do confronto, a vida em contato com a violência se esteriliza, a neobarbárie da praça de guerra concerne tanto aos protegidos quanto aos envolvidos diretamente nela: os protegidos também vivem como miseráveis, são outros miseráveis, aqueles que habitam a clausura da propriedade ("na nossa porta", "na caixa refrigerada"19). A vida protegida alimenta a cultura do medo, produzindo mecanismos de recalque e esquecimento, círculos viciosos de culpabilização e compaixão ou, então, uma aceitação tolerante da desigualdade social, da segregação dos pobres, da imposição de um modo único de vida e consumo. "Sítio" é um raro poema sobre o custo interior dessa sobrevivência.

Dito de forma sumária, o que a poesia de Claudia Roquette-Pinto vem experimentando é um padrão novo de resposta artística à experiência do presente, a partir de formas de meditação que não se subtraem aos aspectos destrutivos das transformações da vida urbana - o mesmo padrão que vejo em Valdo Motta ${ }^{20}$, embora tratado de um ângulo de classe diametralmente oposto. Ao mesmo tempo que entram no conflito social, ambos preferem formas mais complexas de representação que possam captar o desamparo do indivíduo diante da modernidade de forças poderosas que ele não alcança; ambos não acreditam que a verdade da poesia passe incólume pela miséria contemporânea, que está onde menos se espera e não só nos espaços em que se costuma segregá-la. São poetas que assumem a vulnerabilidade da poesia e expõem as carências do sujeito, sempre em correlação com a complexidade de um processo externo, que se cumpreà distância,em cuja atualidade eles identificam situações sociais novas (e seus figurantes) no sítio do contemporâneo, não importa se a referência é clara ou rarefeita. Nesse quadro, o poeta pobre como Valdo Motta olha para a tradição em busca de riquezas que precisam ser expropriadas pelos que não tiveram acesso a elas, com um prazer alegre e destemido de auto-superação; ao passo que um poema como "Sítio", mas sobretudo um livro como Corola, agarram-se à figuração da miséria interior dos protegidos e de um sofrimento intérmino a se atravessar. Enquanto Claudia acentua a intensa e opressiva irrelevância do presente, em que sujeito e humanidade estão acuados, sem consolo nem perspectiva de saída, Valdo Motta desenvolve fantasiosas formas de automistificação que mostram a desproporção entre a grandeza da missão e a 
precariedade de meios de um vate orgulhoso, deblaterando contra as adversidades do mundo.

Se questões dessa ordem voltaram a freqüentar a pauta atual da produção poética brasileira, e podem hoje ser verificadas num conjunto expressivo de obras, são ainda raríssimos os momentos, salvo melhor juízo, em que passam a interferir no processo de composição do poema e a discutir os mecanismos de subjetivação, da imaginação mais privada, da imediatez lírica, das formas de apresentação do mundo contemporâneo - as exceções merecem por esse motivo ser estudadas e debatidas. Sendo assim, não poderia terminar esta análise sem, a título de provocação, perguntar por que a relação com a tão insatisfatória realidade atual demorou tanto a chegar à poesia num país em que a violência é constitutiva da própria sociabilidade:

- Foi preciso que criadores de outra extração social (Paulo Lins, rappers, presidiários, a subliteratura marginal de Ferréz etc.) lançassem publicamente esses temas, por meio de formas que a muitos pareceram toscas e neonaturalistas?

- Ou que o fracasso do neoliberalismo se explicitasse inteiramente, ao longo do segundo mandato de FHC (1998-2002), com sua desmobilização, inércia e agravamento das irresoluções, para que os produtores culturais se animassem a entrar nessa realidade socio-cultural próxima e desconhecida?

- Ou terá sido o próprio atraso da esquerda brasileira, como está seevidenciando no completo êxito do governo Lula, que não estava preparada para pensar de modo independente e criticamente os impasses da sociedade globalizada, sem recursos de desenvolvimento?

- Ou então pode ter sido a massificação vertiginosa da sociedade brasileira posterior a 1964, que fez com que a literatura perdesse a sua audiência de classe e não tenha conseguido se articular com as mudanças sociais vividas desde então?

- $\mathrm{Ou}$ as formas construtivistas das vanguardas poéticas surgidas desde os meados do século XX, em conjunto com as formas de nacionalismo e populismo, que tanto marcaram a poesia brasileira, foram (ou são ainda) impedimento à invenção de experimentos poéticos avançados, capazes de formular a crise contemporânea? É isso o que poderia explicar por que os poetas chegaram tardiamente a esses temas num país quejá teve a antilira de João Cabral, a estética da fome de Glauber Rocha, o Cinema Novo, a obra de Iberê Camargo do período final, a música popular com seus casos de amor e seus casos de polícia, o imaginário da violência social e do mando autoritário em Graciliano Ramos e Guimarães Rosa?

IOu, por fim, a larga aceitação de um ponto de vista teórico e estético que condiciona a existência de complexidade (e criativi- 
[21] Diferentementedo ponto devista que esboço aqui, Flora Süssekind, em "Desterritorialização e forma literária. Literatura brasileira contemporânea e experiência urbana" (Literatura e Sociedade. São Paulo: n8, 2005, pp. 6o-81), apresenta um amplo painel de obras que desenvolvem estratégias de abordagem da violência: “... é fundamentalmente um imaginário do medo e da violência que organiza a paisagem urbana dominante na literatura brasileira" (p. 65). Apesar da abrangência sociológica desse estudo, com muitos dados paralelísticos, sou de opinião que o seu exemplário de espaços não-representacionais e operações de desterritorialização refere-se à violência em geral, sem considerar a particularidade histórica do fenômeno que se alastrou a partir dos meados da década de 1980 .

Recebido para publicação em 23 de outubro de 2008.

\section{NOVOS ESTUDOS}

CEBRAP

82 , novembro 2008

pp. $151-165$ dade) literária à desrealização referencial, à recusa da disciplina mimética, à indeterminação de sua matéria, não terá retardado a incorporação distanciada e crítica da violência contemporânea? Flora Süssekind, que num texto recente chegou à mais acabada formulação desse ponto de vista, é taxativa: só se pode considerar uma obra complexa quando sua formalização não se atém, ou não se rende, à atração mimética e à representação contextual, mas a desestabiliza, ou consegue sabotá-la, pela deriva, dissipação, perversão ou pelo informe (os termos são dela) para potencializar as estratégias do oblíquo ${ }^{21}$. Ou, ao contrário, não seria mais produtivo sugerirque tal preceito da teoria contemporâneaéo que tolhe o conhecimento da experiência pela forma da poesia?

Sabemos que a poesia brasileira contemporânea sofre de verdadeiro complexo de inferioridade diante do padrão ético-engajado do rap mais comercial, profundamente ligado à experiência da pobreza. É claro que poemas como "Sítio" e a poética de Corola são ainda raros e certamente não podem ser considerados uma alternativa ao simultaneísmo tosco e ultra-realista desse gênero musical. Porém, algo decisivo da realidade histórico-social não lhes escapa, nem a poesia permanece impotente e sem voz na circunstância dos conflitos que a afetam, os quais, como vimos, ela interioriza. Por último, para completar esse quadro, não me furtarei a dizer que deveríamos dar o braço a torcer ao fato de que a Indústria Cultural soube se apropriar, reelaborar e apresentar internacionalmente esta sociedade nova e degradada que é o Brasil, na atualidade consternadora de sua luta de classe selvagem e desqualificada rumo a um patamar mais democrático de consumo. Terá sido mais sensível aos fenômenos sociais resultantes do colapso da modernização do que os profissionais exigentes da poesia e da teoria, quer dizer, nós mesmos que estudamos a poesia contemporânea. Para nosso espanto, tenho de perguntar: a arte exigente tem menos inquietação hoje no Brasil do que a vulgaridade da Indústria Cultural?

IUMNA MARIA SIMON é professora de Teoria Literária e Literatura Comparada na Universidade de São Paulo. 